\title{
Relationships among Expectations, Satisfaction and Loyalty of Visitors to Craft Village
}

\author{
NGUYEN THI KIM THANH \\ Electric Power University, Hanoi, VIETNAM \\ 235 Hoang Quoc Viet, Hanoi, VIETNAM \\ NGUYEN QUANG VINH \\ Hanoi University of Business and Technology, Hanoi, VIETNAM \\ 124 Vinh Tuy, Hai Ba Trung, Hanoi, VIETNAM \\ NGO TRONG TUAN \\ Electric Power University, Hanoi, VIETNAM \\ 235 Hoang Quoc Viet, Hanoi, VIETNAM
}

\begin{abstract}
Craft villages play an important role in developing the cultural tourism and improving the attractiveness of cultural characteristics and traditional handcraft products to visitors. Although having many strengths, the development of Vietnamese craft villages tourism is still not commensurate with the inherent potential. The purpose of this study is to assess the relationship among expectations, satisfaction, and loyalty of visitors to craft village tourism in Hanoi. By applying the PLS-SEM method, the research has tested six hypotheses based on the survey results of 236 tourists at two famous tourist village of Hanoi: Bat Trang and Van Phuc. The result shows the positive related of tourists' expectations and tourist perceived value $(\beta=0.6)$, tourist satisfaction $(\beta=0.5)$ and tourist loyalty $(\beta=0.39)$. Similarly, the result indicates the positive relationship of perceived value, satisfaction $(\beta=0.28)$ and tourist loyalty $(\beta=0.2)$. Finally, the testing of the relationship between tourist satisfaction and tourist loyalty has been verified and is supported $(\beta=0.176)$. Conclusions, managerial implication, and suggestions for further studies are also included in the conclusions section of this study.
\end{abstract}

Key-Words: Craft villages tourism, expectation, satisfaction, loyalty, Hanoi Craft villages, Vietnam Tourism

Received: April 27, 2020. Revised: November 16, 2020. Accepted: November 20, 2020. Published: November 23, 2020.

\section{Introduction}

According to the "Vietnam Tourism Development Strategy to 2020, vision to 2030", By the year of 2030 Vietnam becomes a country with a developed tourism industry. With the advantage of abundant and diversified tourism resources, Vietnam will be an attractive destination in the Asia. As mention by Vinh [35] Craft villages tourism is the high-quality cultural tourism, that exploiting the tangible and intangible cultural values and handicraft products made by traditional village laborers. As a tourism resource, the objective of craft villages tourism is to supply the cultural learning, sightseeing, entertainment, especially through which tourists can directly see and participate in some handicraft products, [38]

Hanoi is recognized as the largest concentration of craft villages in Vietnam with 1,350 craft villages, accounting for $59 \%$ of the total number of villages nationwide, of which 277 handicraft villages have been publicized by the city and accepted as traditional craft villages, such as Bat Trang ceramic, Van Phuc silk, Phu Vinh bamboo and rattan, Trieu Khuc weaving, Dai Dong embroidery, Ha Thai lacquer, and Kieu Kieu gold and silver inlaid ... which was dubbed as A unique cultural tourism resource, the traditional trade village of Hanoi also carries with it many potentials, strengths and favorable conditions to develop the type of craft village tourism. However, despite has many strengths with famous brands that have appeared in tourist guidebooks, the development of craft village tourism is still not commensurate with the inherent potential. The rate of visitors to the trade villages compared with the tourists of the whole city is still low and the main revenue comes from selling handicrafts. Tourists' spending on supplemental services is almost nonexistent.

Economic increases leading to increasing of tourism activities and the competitiveness of tourist destinations. Therefore, to attract more tourists than other destinations, the importance key is to create satisfaction and increase visitor loyalty. Studies show that increased destination attractiveness has a positive impact on visitor satisfaction [3] and their loyalty $(23,26]$ is also a factor that influences a visitor's satisfaction and loyalty $[14,34,39]$. Therefore, to have a basis for planning tourism village development, it is necessary to identify the main factors that create the tourist expectation, satisfaction as well as their influence on their loyalty. Although, such studies for tourist 
destinations around the world are conducted quite commonly [ 23, 26, 14, 34, 39]. However, Craft villages tourism studies in Vietnam are still limited. Therefore, this study was conducted to evaluate the relationship of expectations, perceived value, satisfaction and loyalty of through the case of tourists visiting craft villages in Hanoi to give some suggestions for tourism managers, travel marketers in improving the image of the destination, increasing satisfaction and increasing the rate of return visitors.

\section{Literature review}

According to Drivera and Knopf [7], expectations are the beliefs of tourists about a tourist destination or cultural and entertainment activities that can meet certain needs of tourists, the expectation is the source and the reason for approaching or not reacting of a destination. Lin (2008) argues that expectations are desires or needs for a service or product that a service provider should provide, so expectation of the visitor will lead to positive development in decision making with the destination. As study of $\mathrm{Wu}$ and Lin (2012) Expectation measures the ability to expect, demand, failure psychological costs, important expectations of others, the value of work, the degree of swimming involved. Chen et., al [3]; Narangajavana et., al [27] and Lim et., al [23] pointed out that expectation refers to the beliefs that people act to fulfill the desire and beliefs, which determine human behavior, and thus create motivation. As many scholars have different concepts of expectations, this study assumes that tourist expectation with a Craft villages tourism is a response to certain needs or aspirations, that expectations are a short-term belief and determine tourist behavior. In this case, Craft villages tourism need to create the attractive culture activities and provide the high-quality product to meet the tourist expectations.

Perceived value is a consumer appreciation of the value of a product or service $[4,31]$. There is several recent studies have shed light on the importance of perceived value of tourists to the destinations $[31,32,21]$. Perceived values will be changed based on product or service and based on different measured in different regions [21]. Traditionally, perceived value is thought to be a function of product prices, but in recent years, monetary value has been the main indicator of perceived value [8]. Monetary value recognizes the value of a consumer behavior approach to defining perceived value. However, other psychological factors, such as quality, emotional response and reputation, can also influence the decision to purchase a specific product or service [30]. Prebensen and Xie [31] point out the importance of including the mastering and co-creation dimensions in acknowledging tourists' as resource integrators for value creation in experiences. Kim and Park [15], Mai et.al., [24] show the positive relationship among perceived value and tourist satisfaction were a significant antecedent of destination loyalty. However, related perceived value with Craft villages tourism is still limited in the previous literature. Almost of the study is related to culture heritage or rural tourism [31, 22, 24, 17].

Satisfaction related to tourism has been conceptualized and defined in various ways [41]. Torres and Kline [35] noted that customer satisfaction is often seen as a personal perception of the perfection of a product / service in relation to their expectations. Satisfying customer expectations will bring satisfaction. Baker and Crompton [1] regarded tourist satisfaction as the emotional state after touring. Since tourist satisfaction is divided into two categories: Transaction satisfaction is based on the post-purchase evaluation and accumulated satisfaction that is based on an overall evaluation use tourist experiences over time [2]. To determine the level of tourist satisfaction with a specific holiday destination, previous researchers have used various instruments that generate gap scores based on the difference between the expectation and perception of the delivery of particular services associated with that destination $[35,2,41)$. This approach is not holistic in that it does not address the total holiday experience. The expectation can be defined as the ideal or desired performance of the establishment [19]. Chen \& Tsai [5] conducted a study of tourist destination selection, showing that satisfaction is an extension of general pleasure or visitor satisfaction. For further testing, Chi \& Qu [6], Lai and Vinh [20], Vinh [36] has a similar conclusion: attribute satisfaction (operating in the same way as perceived quality) is the premise for tourist satisfaction, attribute satisfaction and Overall satisfaction is the two key determinants of visitor loyalty $[36,33]$.

Prebensen and Xie, [31], Lee et. al. [22], Vinh [36] find that there was a significant correlation between tourist satisfaction and the intention to return to cultural destinations with specific activities causally related to the feature of the site. come. Their study also find that tourism satisfaction has a significantly positive direct correlation with intention to return. In the context of tourism, Kuusik et al [18] note that destination loyalty is 
viewed as a tourist's level of intention to revisit the destination $[36,33]$ and as the tourist's perception of a recommendable place [31]. Similarly, Kuenzel and Katsaris [16] describe post-visit behavior as the intention to return (purchase intention/loyalty) and recommendations through word-of-mouth (WOM). $\mathrm{Chi}$ and $\mathrm{Qu}[6]$ conclude that attribute satisfaction is antecedent to overall satisfaction and that attribute satisfaction and overall satisfaction are both determinants of loyalty. In addition, Mohamad et al. [25] provide empirical evidence that confirmed the positive and significant relationship between tourist satisfaction and destination loyalty. From the findings of previous literature reviews, this study proposes the following hypotheses:

H1: Tourists' expectations is positive related to tourist perceived value with craft village

$\mathrm{H} 2$ : Tourists' expectation is positive related to tourist satisfaction with craft village

H3: Tourist expectations is positive related to tourist loyalty with craft village

H4: Tourist perceived value is positive related to tourist satisfaction with village

H5: Tourist perceived value is positive related to tourist loyalty with craft villages.

H6: Tourist satisfaction is positive related to tourist loyalty with craft Villages.

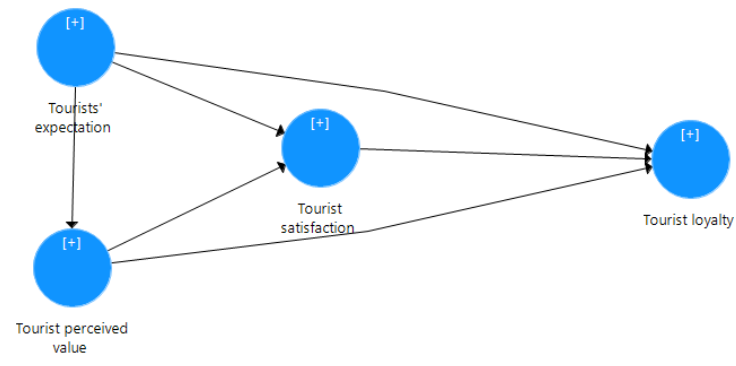

Fig. 1, Research model

\section{Research method}

\subsection{Questionnaire and sample design}

The question in the questionnaire are based on a review of the relevant literature and on interview conducted with tourist and tourism experts. The experts include four professors in tourism faculties and three in tourism industry. Then the questionnaire was distributed for forty tourists in the Van Phuc silk village to confirm the logic of questionnaire (Cronbach anpha pilot test are: tourist expectation is 9.2 ; tourist perceived value is 8.5 ; tourist satisfaction is 8.8 and tourist loyalty is 7.8 ). The questionnaire consists of three parts: the first part is demographic information of respondent, the second part is the questionnaire related to the factors: the tourist expectation include 10 items that developed from study of Murphy, et al. [26] Torres and Kline [35] and Lim et., al [23] the tourist perceived value include three item that developed from study of Prebensen and Xie, [31] Mai et.al. [24] the tourist satisfaction includes three factor that developed from study of Bogale et. al. [2] and Zhang et. al. []41. The third part of questionnaire is related to tourist loyalty factor include three item the were revised from study of Prebensen and Xie [31], Lee et. al., [22] Vinh [36] ( I would choose the destination again for my future travel; I will recommend the destination to friends and relatives; I will recommend the destination through social networks such as: Facebooks, Twister, Instagram etc.). All questions regarding tourist expectation, tourist perceived value, tourist satisfaction and destination loyalty were measured by five-point Likert scales (ranging from $1=$ strongly disagree to $5=$ strongly agree).

As the purpose of the study is to identify and analyze the relationship between expectations, satisfaction and loyalty of visitors to craft village tourism in Hanoi. after visiting Vietnam, the primary data were finally collected in December 2019 and January 2020 in Vanphuc silk village and Battrang ceramic village in Hanoi. After distributing a total of 300 questionnaires over 5 weeks, 287 questionnaires were collected, 51 of which were incomplete. The usable and effective questionnaires for this study totaled 236, representing a response rate of $78,6 \%$.

\subsection{Measures}

The questionnaire was originally prepared in English. The statistical package for SPSS version 22.0 and the partial least square structural equation modeling tool SmartPLS 3.0 were used to analyze the data for the questionnaires. First, an explorative factor analysis (EFA) using the principle component method was performed to reduce the number of variables and to look for underlying constructs within the data. Data were checked for suitability for this type of analysis. This study calculated the determinant of the correlation matrix to eliminate the extreme correlations between different variables, and then followed with the assumption that a factor analysis for those correlations among variables would be moderate. Second, based on the questionnaire, an appropriate assessment for partial least square structural equation modeling was used to assess the validity and reliability of the constructs of the measurement scales [13]. Finally, a series of steps using SEM analysis was utilized to test the moderating significance of the hypotheses. The hypothesized relationships depicted in Figure 1 were measured using SmartPLS 3.0 through path analysis. All hypotheses in this study were 
developed based on empirical evidence from previous studies.

\section{Result analysis}

\subsection{Respondent profile}

The usable questionnaire shows that among 236 respondents, there is 152 people is male account for $64.4 \%$ and female is 84 people and account for $35.6 \%$. A plurality of the visitors fell into the $26-45$ years old age group, representing $42.8 \%$ of the respondents. Respondents older than 60 years of age were few, accounting for only $9.7 \%$. the survey revealed that the education level of tourists traveling to Vietnam was relatively high, with $72 \%$ having earned at least a bachelor's degree. Only $15.7 \%$ of respondents had no higher than a high school education. Most of the tourists were first-time visitors $(64.4 \%)$. With regard to their career for visiting, the survey revealed that $43.6 \%$ of the visitors reported as office staff or worker, $6.4 \%$ is businessmen, student is $17.8 \%$ and $32.2 \%$ indicated as others. Regarding tourist nationality, $20.8 \%$ were visiting from China, $19.5 \%$ were visiting from the United States and 13.6\% were visiting from Europe, Just $11.4 \%$ of the visitors were Asean countries, $14 \%$ visitors were Asia and the remaining $20.8 \%$ were visiting from other countries. Regarding the information source: $49.6 \%$ visitor information source come from internet, $25.4 \%$ from television and remaining $25 \%$ from others sources. Table 1 shows the respondent profile.

Table 1, Respondent profile

\begin{tabular}{llcc}
\hline \multicolumn{2}{l}{ Demographic characteristic } & Frequency & Percentage \\
& & & \\
\hline Gender & Male & 152 & 64.4 \\
Age & Female & 84 & 35.6 \\
& Below 25 & 36 & 15.3 \\
& $26-45$ & 101 & 42.8 \\
& $45-60$ & 76 & 32.2 \\
Career & Over 60 & 23 & 9.7 \\
& Businessmen & 15 & 6.4 \\
& Student & 42 & 17.8 \\
& Staff & 103 & 43.6 \\
Education & Others & 76 & 32.2 \\
& High school or & 37 & 15.7 \\
& lower & 170 & 72.0 \\
& Bachelor & 29 & 12.3 \\
Experience & Master or higher & 84 & 35.6 \\
\multirow{5}{*}{ Nationality } & Repeaters & 152 & 64.4 \\
& First-timers & 46 & 19.5 \\
& USA & 49 & 20.8 \\
& China & 32 & 13.6 \\
& Europe & 27 & 11.4
\end{tabular}

\begin{tabular}{|c|c|c|c|}
\hline \multirow{5}{*}{$\begin{array}{l}\text { Information } \\
\text { source }\end{array}$} & Asia & 33 & 14.0 \\
\hline & Others & 49 & 20.8 \\
\hline & Internet & 117 & 49.6 \\
\hline & TV & 60 & 25.4 \\
\hline & Others & 59 & 25.0 \\
\hline Total & & 236 & 100.0 \\
\hline
\end{tabular}

Table 2, Reliability and construct validity

\begin{tabular}{lllll}
\hline & $\begin{array}{l}\text { Cronb } \\
\text { ach's } \\
\text { Alpha }\end{array}$ & $\begin{array}{l}\text { rho_ } \\
\text { A }\end{array}$ & $\begin{array}{l}\text { Composit } \\
\text { e } \\
\text { Reliability }\end{array}$ & $\begin{array}{l}\text { Average } \\
\text { Variance } \\
\text { Extracte } \\
\text { d (AVE) }\end{array}$ \\
\hline $\begin{array}{lllll}\text { Expectation } \\
\text { Perceived }\end{array}$ & 0.914 & 0.918 & 0.928 & 0.565 \\
value & 0.876 & 0.884 & 0.924 & 0.801 \\
Satisfaction & 0.882 & 0.886 & 0.927 & 0.809 \\
Loyalty & 0.783 & 0.817 & 0.874 & 0.700 \\
\hline
\end{tabular}

Table 2 show the reliability and construct validity Cronbach's Alpha Index is a traditional reliability measure; composite Reliability index is more commonly used for PLS-SEM analysis; The variance index (AVE) is also an important indicator for data evaluation. The data ensures reliability since Cronbach's Alpha and composite Reliability are greater than 0.7 and AVE is greater than 0.5, Therefore, all of the factors were accepted and deemed reliable, as recommended by Hair, et al.[11].

The results in Table 3 indicate that there are 2 observed variables with a core value less than 0.7 which have been excluded from the model, including: The beauty of nature (EXP3); Local cuisine (EXP4).

Table 3, Loading factor matrix

\begin{tabular}{lcccc}
\hline & $\begin{array}{c}\text { Expectatio } \\
\mathrm{n}\end{array}$ & $\begin{array}{c}\text { Perceived } \\
\text { value }\end{array}$ & $\begin{array}{c}\text { Satisfactio } \\
\mathrm{n}\end{array}$ & $\begin{array}{c}\text { Loyalt } \\
\mathrm{y}\end{array}$ \\
\hline EXP1 & $\mathbf{0 . 7 3 2}$ & 0.422 & 0.470 & 0.484 \\
EXP2 & $\mathbf{0 . 7 1 5}$ & 0.371 & 0.453 & 0.337 \\
EXP5 & $\mathbf{0 . 7 2 6}$ & 0.543 & 0.509 & 0.516 \\
EXP6 & $\mathbf{0 . 7 6 8}$ & 0.515 & 0.550 & 0.572 \\
EXP7 & $\mathbf{0 . 7 6 2}$ & 0.504 & 0.518 & 0.489 \\
EXP8 & $\mathbf{0 . 8 3 7}$ & 0.472 & 0.580 & 0.552 \\
EXP9 & $\mathbf{0 . 7 9 5}$ & 0.425 & 0.522 & 0.459 \\
EXP10 & $\mathbf{0 . 7 6 6}$ & 0.450 & 0.468 & 0.486 \\
PER1 & 0.521 & $\mathbf{0 . 9 1 4}$ & 0.442 & 0.489 \\
PER2 & 0.491 & $\mathbf{0 . 8 9 0}$ & 0.515 & 0.414 \\
PER3 & 0.591 & $\mathbf{0 . 8 8 1}$ & 0.588 & 0.533 \\
SAT1 & 0.548 & 0.513 & $\mathbf{0 . 8 8 5}$ & 0.459 \\
\hline
\end{tabular}




\begin{tabular}{lllll}
\hline SAT2 & 0.655 & 0.530 & $\mathbf{0 . 9 2 4}$ & 0.545 \\
SAT3 & 0.594 & 0.525 & $\mathbf{0 . 8 9 0}$ & 0.487 \\
LOY1 & 0.762 & 0.399 & 0.484 & $\mathbf{0 . 7 0 9}$ \\
LOY2 & 0.608 & 0.526 & 0.577 & $\mathbf{0 . 8 9 6}$ \\
LOY3 & 0.538 & 0.474 & 0.507 & $\mathbf{0 . 8 8 6}$ \\
\hline
\end{tabular}

The discriminant validity was found to be evident in the AVE because the constructs were greater than the squared correlation between the constructs, and hence the relationships between measures and constructs were stronger than the relationships between constructs themselves. This result indicates that all the items have an acceptable convergent validity and discriminant validity in explaining the theorized constructs [12]

Table 4, Discriminant validity

\begin{tabular}{lllll}
\hline & $\begin{array}{l}\text { Expectat } \\
\text { ion }\end{array}$ & $\begin{array}{l}\text { Perceived } \\
\text { value }\end{array}$ & $\begin{array}{l}\text { Satisfact } \\
\text { ion }\end{array}$ & $\begin{array}{l}\text { Loya } \\
\text { lty }\end{array}$ \\
\hline $\begin{array}{l}\text { Expectatio } \\
\mathrm{n}\end{array}$ & 0.751 & & & \\
$\begin{array}{l}\text { Perceived } \\
\text { value }\end{array}$ & 0.602 & 0.895 & & \\
$\begin{array}{l}\text { Satisfaction } \\
\text { Loyalty }\end{array}$ & 0.554 & 0.581 & 0.900 & \\
\hline
\end{tabular}

Table $5, \mathrm{VIF}, \mathrm{f}^{2}, \mathrm{R}^{2}$ và $\mathrm{R}^{2}$ Adjusted Value

\begin{tabular}{|c|c|c|c|c|c|c|c|c|}
\hline & \multicolumn{2}{|c|}{$\begin{array}{l}\text { Expectati } \\
\text { on }\end{array}$} & \multicolumn{2}{|c|}{$\begin{array}{l}\text { Perceived } \\
\text { value }\end{array}$} & \multicolumn{2}{|c|}{$\begin{array}{l}\text { Satisfacti } \\
\text { on }\end{array}$} & \multirow{2}{*}{$\mathrm{R}^{2}$} & \multirow{2}{*}{$\begin{array}{c}\mathrm{R}^{2} \\
\text { Adju } \\
\text { sted }\end{array}$} \\
\hline & $\begin{array}{l}\text { (VI } \\
\mathrm{F})\end{array}$ & $\mathrm{f}^{2}$ & $\begin{array}{c}\text { (VI } \\
\mathrm{F})\end{array}$ & $\mathrm{f}^{2}$ & $\begin{array}{c}\text { (VI } \\
\mathrm{F})\end{array}$ & $\mathrm{f}^{2}$ & & \\
\hline Perceive & 1.0 & 0.2 & & & & & 0.4 & 0.45 \\
\hline $\mathrm{d}$ value & 00 & 67 & & & & & 62 & 7 \\
\hline Satisfacti & 1.5 & 0.2 & 1.4 & 0.0 & & & 0.4 & 0.45 \\
\hline on & 67 & 17 & 71 & 99 & & & 59 & 2 \\
\hline Lovalty & 2.0 & 0.1 & 1.7 & 0.0 & 1.9 & 0.0 & 0.4 & 0.49 \\
\hline Loyalty & 64 & 41 & 23 & 43 & 87 & 29 & 97 & 3 \\
\hline
\end{tabular}

The table 5 shows the value of the variance inflation factor (VIF) of all variables in the model is less than 3 indicate no multicollinearity problem as suggested by Hair, et al., (2014). The next indicator to consider is the $\mathrm{R} 2$ value of the structured variables. Significant value levels of R2 depend on the application applied. The R2 values in Table 5 shows the appropriate level in this study. The value of $\mathrm{f} 2$ function represents the level of influence of the structure when removed from the model. Structures with $\mathrm{f} 2$ values less than 0.02 demonstrate a low level of influence in the model. In this model, all links are highly influential (f2> 0.02). Thereby indicating an acceptable fit

\subsection{Structural Model Analysis}

This study proposed six hypotheses, table 6 and fig. 2 shows the result of hypothesis testing.

Table 6: Result of hypothesis testing

\begin{tabular}{|c|c|c|c|c|}
\hline Path & $\mathrm{O}$ & $\mathrm{T}$ & $\mathrm{P}$ & $\begin{array}{c}\text { Hypothes } \\
\text { is result }\end{array}$ \\
\hline $\begin{array}{l}\text { Expectation } \quad-> \\
\text { Perceived value }\end{array}$ & 0.602 & 9.686 & 0.000 & supported \\
\hline $\begin{array}{l}\text { Expectation } \quad-> \\
\text { Satisfaction }\end{array}$ & 0.500 & 6.798 & 0.000 & supported \\
\hline $\begin{array}{l}\text { Expectation } \quad-> \\
\text { Loyalty }\end{array}$ & 0.397 & 5.471 & 0.000 & supported \\
\hline $\begin{array}{l}\text { Perceived } \\
\text { value-> } \\
\text { Satisfaction }\end{array}$ & 0.280 & 3.857 & 0.000 & supported \\
\hline $\begin{array}{l}\text { Perceived } \\
\text { value-> Loyalty }\end{array}$ & 0.200 & 3.412 & 0.001 & supported \\
\hline $\begin{array}{l}\text { Satisfaction } \quad-> \\
\text { Loyalty }\end{array}$ & 0.176 & 2.190 & 0.029 & supported \\
\hline
\end{tabular}

All hypothetical relationships in conceptual model are supported. The result shows that tourists' expectations is positive related to tourist perceived value with craft village with the value of $\beta=0.6$ ( $\mathrm{t}=9.686 ; \mathrm{p}<0.05)$, tourists' expectations is positive related to tourist satisfaction value with craft village with the value of $\beta=0.5(t=6.798 ; p<0.05)$ and Tourist expectations is positive related to tourist loyalty with craft village with the value of $\beta=0.39$ ( $\mathrm{t}=5.471 ; \mathrm{p}<0.05)$. This results show a very interesting finding that the rank of the relatioships between expectations for the remaining variables: perceived values, satisfaction and loyalty are very high, it means that the gap between expectations and satisfaction has been shortened. It contrasts with previous studies results, a number of previous studies on Vietnam tourism shows the long gap among expectations for a Vietnamese destination and satisfaction or event have the negative relatinship $[28,37,17)$.

Similarly, the result indicated the positve relationship of percived value, satisfaction $(\beta=$ $0.28, \mathrm{t}=3,857 ; \mathrm{p}<0.05)$ and tourist loyalty $(\beta=$ $0.2, t=3.412 ; \mathrm{p}<0.05)$. Finally, the testing of the relationship between tourist satisfaction and tourist loyalty (the higher the overall satisfaction, the more positive the destination loyalty is) has been verified and is supported $(\beta=0.176(t=219 ; \mathrm{p}<0.05)$. This finding corroborates the findings of previous studies such as $[36,9,33,28]$. 


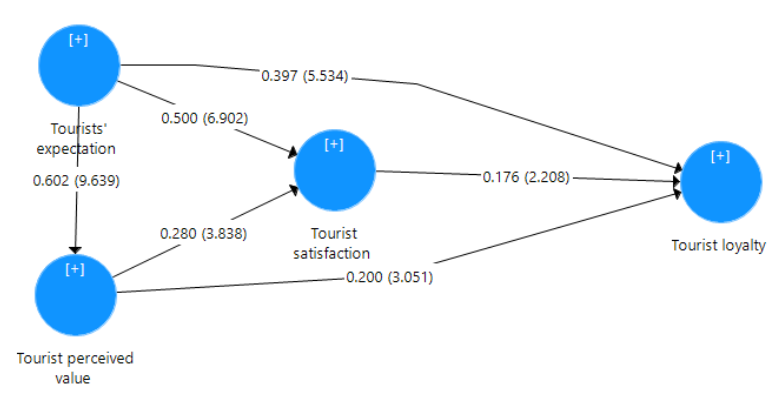

Fig. 2, Model result

\section{Conclusion}

Aming to assess the relationship of tourist expectation, satisfaction and loyalty with the craft village in Hanoi, Vietnam. This study used 236 questionnaires from international visitors who visited two craft village included Battrang ceramic village and Vanphuc silk village. The partial least square structural equation mode was used to verify the proposed hypotheses.

The results indicated that all six hypotheses are supported. These results show some similarities with previous studies while showing the link between perceived value - satisfaction - loyalty (traditional model in tourism research such as: [36, 9, 33 and 28.) Besides, the study also showed the links between expectations - perceived value; expectations - the satisfaction and expectations loyalty is strongly supported with a value of $\beta$, respectively: $0.602 ; 0.500$ and 0.397 . As mentioned, previous studies often show the positive relationship of expectations and perceived values $[15,20,22$, 24]. However, this study shows a strong positive relationship between expectations and satisfaction and loyalty, which will be an important finding for tourism marketers in promoting the image of the destination. Vietnam marketers expect to realize the visitor's dreams to experience quality service with a high quality based experience. In order to realize this ambition, any experience should include all the elements that attract visitors. The effect of satisfaction on the loyalty of tourists to the destination of craft villages in Hanoi with a value of $\beta=0.176$. This result is consistent with those of Chen and Tsai [5], Žabka et al. [40], Vinh, [36] and Suhartanto, [33] which all provide empirical evidence confirming a positive and significant relationship between tourist satisfaction and destination loyalty in culture heritage tourism. However, in their studies, the perceived quality is considered as the mediating variable for tourist satisfaction and destination loyalty $[5,40]$
From the perspective of managers, tourism marketing, especially for cultural tourism sites (the strengths of Vietnam), cultural activities in the tourist area need to be organized and diversified. Especially, tourists were extremely impressed with the activities of hand-crafting ceramic products in Bat Trang village, or activities to explore the silk production process of Vanphuc village. Those activity really impresses visitors, so marketers need to stand out more to attract the attention of tourists to traditional village tourism. In addition, the quality of service needs to continue to improve, especially the staff at the destination (guides, salespeople at souvenir shops, waiters at restaurants, accommodation facilities ...) in recent years there has been a significant improvement in service quality, but currently Vietnam in general and Hanoi in particular are still underestimated in terms of service quality (Thuy et al. 2019 and $\mathrm{Ha}$, et al. 2019). Because of the quality of service, the return rate of tourists is still low (specifically in this case, it is over $30 \%$ ).

Although this study contributes to the theoretical and managerial implications, the model used in this study should be more developed regarding trip quality and destination image in the future. The study only conducted surveys in two locations of Hanoi craft villages, while other craft villages should also be surveyed, the attributes of expectations have not focused specifically on tourism activities of a craft village. Also, future studies with larger samples could be conducted to allow for comparisons between national and foreign tourist behaviors as well as between experienced and non-experienced tourists.

\section{References:}

[1] Baker, D. A., \& Crompton, J. L. (2000). Quality, satisfaction and behavioral intentions. Annals of tourism research, 27(3), 785-804.

[2] Bogale, S. A., Verhees, F. J., \& Trijp, H. C. V. (2018). Customer Evaluation of Supply Systems: The Case of Ethiopian Seed Supply Systems. Journal of African Business, 19(4), 550-570.

[3] Chen, C. C., Huang, W. J., \& Petrick, J. F. (2016). Holiday recovery experiences, tourism satisfaction and life satisfaction-Is there a relationship?. Tourism Management, 53, 140-147.

[4] Chen, C. F., \& Chen, F. S. (2010). Experience quality, perceived value, satisfaction and behavioral intentions for 
heritage tourists. Tourism management, 31(1), 29-35.

[5] Chen, C. F., \& Tsai, D. (2007). How destination image and evaluative factors affect behavioral intentions? Tourism Management, 28, 1115-1122

[6] Chi, C. G. Q., \& Qu, H. (2008). Examining the structural relationships of destination image, tourist satisfaction and destination loyalty: An integrated approach. Tourism management, 29(4), 624-636.

[7] Driver, B. L., \& Knopf, R. C. (1977). Personality, outdoor recreation, and expected consequences. Environment and Behavior, 9(2), 169-193.

[8] Gallarza, M. G., \& Saura, I. G. (2006). Value dimensions, perceived value, satisfaction and loyalty: an investigation of university students' travel behaviour. Tourism management, 27(3), 437-452.

[9] Guo, Y., Barnes, S. J., \& Jia, Q. (2017). Mining meaning from online ratings and reviews: Tourist satisfaction analysis using latent dirichlet allocation. Tourism Management, 59, 467-483.

[10] Ha, N. T., \& Anh, C. L. (2019). Internal service quality, external service quality, employee Satisfaction and customer Satisfaction for Vietnamese hotels: A Theoretical Approach. VNU Journal of Science: Economics and Business, 35(4).

[11] Hair Jr, J. F., Hult, G. T. M., Ringle, C., \& Sarstedt, M. (2016). A primer on partial least squares structural equation modeling $(P L S-S E M)$. Sage publications.

[12] Hair Jr, J. F., Sarstedt, M., Hopkins, L., \& Kuppelwieser, V. G. (2014). Partial least squares structural equation modeling (PLSSEM). European business review.

[13] Henseler, J., \& Chin, W. W. (2010). A comparison of approaches for the analysis of interaction effects between latent variables using partial least squares path modeling. Structural Equation Modeling, 17(1), 82-109.

[14] Hung, K., \& Petrick, J. F. (2012). Testing the effects of congruity, travel constraints, and self-efficacy on travel intentions: An alternative decision-making model. Tourism Management, 33(4), 855-867.

[15] Kim, K. H., \& Park, D. B. (2017). Relationships among perceived value, satisfaction, and loyalty: Community-based ecotourism in Korea. Journal of Travel \& Tourism Marketing, 34(2), 171-191.
[16] Kuenzel, S., \& Katsaris, N. (2009). A critical analysis of service recovery processes in the hotel industry. TMC Academic Journal, 4(1), 1-11.

[17] Kumar, A. (2019). A study on gender differences in motives of visit intention, perceived value and tourist satisfaction with rural tourism in India. International Journal on Customer Relations, 16.

[18] Kuusik, A., Tiru, M., Ahas, R., \& Varblane, U. (2011). Innovation in destination marketing: The use of passive mobile positioning for the segmentation of repeat visitors in Estonia. Baltic Journal of Management, 6(3), 378-399.

[19] Lai, W. H., \& Vinh, N. Q. (2013). How promotional activities and evaluative factors affect destination loyalty: Evidence from international tourists of Vietnam. International Journal of Marketing Studies, $5(1), 70$.

[20] Lai, W. H., \& Vinh, N. Q. (2013). Online promotion and its influence on destination awareness and loyalty in the tourism industry. Advances in Management and Applied Economics, 3(3), 15.

[21] Lee, H. Y., Qu, H., \& Kim, Y. S. (2007). A study of the impact of personal innovativeness on online travel shopping behavior - A case study of Korean travelers. Tourism Management, 28(3), 886-897.

[22] Lee, S., Phau, I., Hughes, M., Li, Y. F., \& Quintal, V. (2016). Heritage tourism in Singapore Chinatown: A perceived value approach to authenticity and satisfaction. Journal of Travel \& Tourism Marketing, 33(7), 981-998.

[23] Lim, K. Y., Gong, W., Wong, C. F., Ng, A., Hong, H., Jia, S., \& Tan, O. K. (2019). The Tourist Satisfaction Based On The Service Quality Of Tourism In Guizhou, China. INTI JOURNAL, 2019(43).

[24] Mai, K. N., Nguyen, P. N. D., \& Nguyen, P. T. M. (2019). International Tourists' Loyalty to Ho Chi Minh City DestinationA Mediation Analysis of Perceived Service Quality and Perceived Value. Sustainability, 11(19), 5447.

[25] Mohamad, M., Abdullah, A. R., \& Mokhlis, S. (2011). Examining the Influence of Service Recovery Satisfaction on Destination Loyalty: A Structural Equation Modelling. Journal of Sustainable Development, 4(6), 3. 
[26] Murphy, L., Moscardo, G., Benckendorff, P., \& Pearce, P. (2011). Evaluating tourist satisfaction with the retail experience in a typical tourist shopping village. Journal of retailing and Consumer Services, 18(4), 302-310.

[27] Narangajavana, Y., Fiol, L. J. C., Tena, M. Á. M., Artola, R. M. R., \& García, J. S. (2017). The influence of social media in creating expectations. An empirical study for a tourist destination. Annals of Tourism Research, 65, 60-70.

[28] Nguyen Quang Vinh (2019) Homestay Tourism: Culture Destination and Tourism Satisfaction. Journal of Business and Technology, 2, 68-76

[29] Pandža Bajs, I. (2015). Tourist perceived value, relationship to satisfaction, and behavioral intentions: The example of the Croatian tourist destination Dubrovnik. Journal of Travel Research, 54(1), 122-134.

[30] Petrick, J. F. (2002). Development of a multi-dimensional scale for measuring the perceived value of a service. Journal of leisure research, 34(2), 119-134.

[31] Prebensen, N. K., \& Xie, J. (2017). Efficacy of co-creation and mastering on perceived value and satisfaction in tourists' consumption. Tourism Management, 60, 166-176.

[32] Ryu, K., Lee, H. R., \& Kim, W. G. (2012). The influence of the quality of the physical environment, food, and service on restaurant image, customer perceived value, customer satisfaction, and behavioral intentions. International journal of contemporary hospitality management.

[33] Suhartanto, D. (2018). Tourist satisfaction with souvenir shopping: evidence from Indonesian domestic tourists. Current Issues in Tourism, 21(6), 663-679.

[34] Thuy, V. T. N., Tuu, H. H., Llosa, S., \& Thao, H. D. P. (2019). An application of Tetraclass model for evaluating ecotourism service quality in Vietnam. Tourism and Hospitality Research, 1467358419867741.

[35] Torres, E. N., \& Kline, S. (2013). From customer satisfaction to customer delight. International Journal of Contemporary Hospitality Management.

[36] Vinh, N. Q. (2013). Destination culture and its influence on tourist motivation and tourist satisfaction of homestay visit. Journal of The Faculty of Economics and Administrative Sciences, 3(2), 1999-222.
[37] Vinh, N. Q., \& Long, N. L. (2013). The relationship among expectation, satisfaction and loyalty of international visitor to Hanoi, Vietnam. Journal of global management, $5(1)$.

[38] Vitasurya, V. R. (2016). Local wisdom for sustainable development of rural tourism, case on Kalibiru and Lopati village, province of Daerah Istimewa Yogyakarta. Procedia-Social and Behavioral Sciences, 216(6), 97-108.

[39] Wang, C., Qu, H., \& Hsu, M. K. (2016). Toward an integrated model of tourist expectation formation and gender difference. Tourism Management, 54, 5871.

[40] Žabka, V., Brenc`ic ${ }^{\sim}, \quad$ M. M., \& Dmitrovic', T. (2010). Modeling perceived quality, visitor satisfaction and behavioral intentions at the destination level. Tourism Management, 31(4), 537-546.

[41] Zhang, H., Cho, T., Wang, H., \& Ge, Q. (2018). The influence of cross-cultural awareness and tourist experience on authenticity, tourist satisfaction and acculturation in World Cultural Heritage Sites of Korea. Sustainability, 10(4), 927.

\section{Creative Commons Attribution License 4.0 (Attribution 4.0 International, CC BY 4.0)}

This article is published under the terms of the Creative Commons Attribution License 4.0

https://creativecommons.org/licenses/by/4.0/deed.en_US 